\title{
Kajian Agronomi Potensi Pengembangan Tanaman Sorgum Varietas Numbu di Kabupaten Ende
}

\author{
Agronomic Study on the Potential Development of Numbu Sorghum Variety in Ende Regency
}

\author{
Murdaningsih*, Adrianus F.G. Uran
}

Program Studi Agroteknologi, Fakultas Pertanian, Universitas Flores, Jalan Sam Ratulangi, Ende 86316, Indonesia

*E-mail Penulis Korespondensi: murdaningsih11@gmail.com

\begin{abstract}
Sorghum is a cereal crop that has the potential to be developed on dry land as a food source, has the ability to adapt widely, and requires less agricultural inputs than other food crops. Ende Regency is an area that has a dry climate and is dominated by dry land agriculture, so it has the potential for the development of sorghum plants. The purpose of this study was to conduct an agronomic study of the development of Nambu sorghum variety with the application of chicken manure. The research was conducted using a randomized block design, with 5 treatments chicken manure doses, i.e. A0: 0 tons per ha (control), Al: 3.25 tons per ha, A2: 6.5 tons per ha, A3: 9.75 tons per ha, and A4: 13 tons per ha. The application of chicken manure of 13 tons per ha to sorghum plants resulted in growth and yield variables with the highest values, i.e., plant height $277.08 \mathrm{~cm}$, leaf number 15.69 pieces, leaf area $8720.03 \mathrm{~cm}^{2}$, fresh stover weight base $354.69 \mathrm{~g}$, dry stover weight $249.38 \mathrm{~g}$, panicle length $20.54 \mathrm{~g}$, panicle dry weight $24.63 \mathrm{~g}$, number of seeds per panicle $1392.19 \mathrm{~g}, 1000$ seeds weight $7.50 \mathrm{~g}$.
\end{abstract}

Keywords: Chicken manure, dry land, food, sorghum.

\section{ABSTRAK}

Sorgum merupakan tanaman serealia yang berpotensi untuk dikembangkan pada lahan kering sebagai sumber pangan, memiliki kemampuan beradaptasi secara luas, serta membutuhkan input pertanian relatif lebih sedikit dibandingkan tanaman pangan lainnya. Kabupaten Ende merupakan daerah yang beriklim kering dan dengan dominasi pertanian lahan kering, sehingga berpotensi untuk pengembangan tanaman sorgum. Tujuan penelitian ini adalah untuk melakukan kajian agronomis pengembangan tanaman sorgum varietas Nambu dengan aplikasi pupuk kandang ayam. Penelitan dilakukan dengan percobaan menggunakan rancangan acak kelompok, dengan 5 perlakuan penggunaan pupuk kandang ayam, yakni $\mathrm{A}_{0}: 0$ ton per ha (kontrol), $\mathrm{A}_{1}: 3,25$ ton per ha, $\mathrm{A}_{2}: 6,5$ ton per ha, $A_{3}: 9,75$ ton per ha, dan A4: 13 ton per ha. Aplikasi pupuk kandang ayam sebesar 13 ton per ha terhadap tanaman sorgum menghasilkan variabel-variabel pertumbuhan dan hasil dengan nilai-nilai tertinggi, yaitu tinggi tanaman $277,08 \mathrm{~cm}$, jumlah daun 15,69 helai, luas daun $8720,03 \mathrm{~cm}^{2}$, bobot brangkasan basah 354,69 g, bobot brangkasan kering 249,38 g, panjang malai 20,54 g, bobot malai kering 24,63 g, jumlah biji per malai 1392,19 g, bobot 1000 biji 7,50 g.

Kata Kunci: Lahan kering, pangan, pupuk kandang ayam, sorgum.

\section{PENDAHULUAN}

Sorgum (Sorghum bicolor (L.) Moench) merupakan tanaman serealia yang dapat tumbuh pada berbagai keadaan lingkungan sehingga potensial dikembangkan, khususnya pada lahan marginal beriklim kering di Indonesia. Keunggulan sorgum terletak pada daya adaptasinya yang luas, toleransi terhadap kekeringan, produktivitas tinggi, dan ketahanannya yang lebih tinggi terhadap hama dan penyakit dibandingkan dengan tanaman pangan lainnya. Selain budidayanya yang mudah, sorgum mempunyai manfaat yang luas, antara lain untuk pakan, pangan, dan bahan industri. Di negara-negara berkembang, sorgum dibudidayakan sebagai bahan pangan dan minuman beralkohol atau bahan upacara adat (Andriani dan Isnaini, 2013)

Masyarakat yang mengkonsumsi sorgum sering kali dianggap sebagai masyarakat marginal. Padahal sorgum mempunyai mutu gizi yang lebih unggul dibandingkan dengan tanaman serealia lainnya, antara lain mengandung karbohidrat ( $\pm 70 \%$ ), protein (8-12\%) dan lemak (2-6\%) serta berbagai mineral esensial, seperti $\mathrm{P}, \mathrm{Mg}, \mathrm{Ca}, \mathrm{Fe}, \mathrm{Zn}, \mathrm{Cu}$, Mn, Mo dan Cr. Kendala utama dalam pemanfaatan sorgum sebagai bahan pangan adalah penyosohan dan kendala ini sudah dapat diatasi. Sorgum sosoh (beras sorgum) dapat dikonsumsi seperti nasi (Widowati, 2010)

Salah satu masalah yang dihadapi Indonesia berkaitan dengan ketahanan pangan adalah ketergantungan terhadap bahan pangan impor, terutama beras dan gandum. Untuk mengatasi masalah tersebut maka perlu dikembangkan bahan pangan lokal lain yang dapat mensubstitusi bahan pangan tersebut dan dapat dikembangkan pada lahan kering yang umumnya memiliki kesuburan rendah, peka terhadap erosi dan ketersediaan air terbatas. Sorgum merupakan tanaman pangan lokal yang dapat dikembangkan pada lahan kering (Irawan dan Sutrisna, 2011). 
Sorgum adalah tanaman pangan yang berpotensi untuk dikembangkan dalam sistem pertanian lahan kering dan untuk mendukung ketahanan pangan di Indonesia. Sorgum dapat dimanfaatkan sebagai sumber makanan, yang memiliki kemampuan beradaptasi secara luas, membutuhkan input pertanian lebih sedikit daripada tanaman pangan lainnya (Human, 2011). Sorgum merupakan tanaman semusim yang toleran kekeringan dan tidak banyak memerlukan air selama pertumbuhannya. Daya adaptasi yang cukup baik pada lahan kering dan tumbuh baik dengan input minimal, sehingga sorgum berkembang luas. Sorgum mudah dibudidayakan pada semua agroekologi lahan pertanian di Indonesia (Sumarno et al., 2013). Tanaman Sorgum sangat cocok untuk pertanian lahan kering sehingga mereka memiliki peluang untuk dibudidayakan di daerah yang memiliki masalah kelangkaan air untuk meningkatkan produktivitas lahan (Human, 2011)

Sorgum dapat merupakan salah satu komoditi pangan potensial yang dapat dikembangkan untuk mendukung program diversifikasi pangan di Indonesia (Subagio dan Aqil, 2013). Potensi Pengembangan sorgum di Indonesia cukup besar, karena memiliki adaptasi yang luas, terutama di lahan marginal (Sirappa, 2003). Masalah pengembangan usaha tani sorgum di tingkat petani adalah pengusahaannya belum intensif. Untuk mengatasi masalah tersebut diperlukan pengelolaan sistem produksi sorgum secara menyeluruh (holistik) berkaitan dengan wilayah, nilai keunggulan komparatif dan kompetitif sorgum dibandingkan tanaman pangan lainnya, sosial dan industri ( Sirappa, 2003; Gunawan, 2017). Optimalisasi pengembangan produksi sorgum dalam skala besar akan menimbulkan terjadinya kompetisi penggunaan lahan dengan komoditas lain, sehingga dapat diarahkan pada lahan marjinal serta lahan non produktif yang banyak tersebar di wilayah tengah dan timur Indonesia (Subagio dan Aqil, 2013). Sorgum dapat dikembangkan sebagai suplementasi pangan pokok beras dan komponen ransum pakan (Sumarno et al., 2013).

Pemilihan varietas sorgum yang toleran terhadap kondisi buruk (kekeringan dan keasaman tanah), dan adaptif dengan sistem pertanian dataran rendah, sangat dianjurkan (Human, 2011). Saat ini telah tersedia 11 varietas sorgum dengan daya hasil cukup tinggi, berumur genjah serta daya adaptasi yang luas (Subagio dan Aqil, 2013). Varietas yang sangat toleran terhadap kekeringan adalah vaeietas Nambu. Perbedaan genotipe sorgum dapat dikenali lebih jelas pada fase generatif dibandingkan fase vegetatif (Kusumawati et al., 2013)

Produksi tanaman di Nusa Tenggara Timur pada tahun 2019 untuk tanaman pangan utama (padi, jagung dan kedelai) adalah sebesar 1.500.422 ton (BPS NTT, 2020), dan sumbangan produksi sorgum masih relatif kecil. Kabupaten Ende berada ditengah-tengah pulau Flores. Pulau Flores berada di Indonesia bagian Timur memiliki topografi yang beragam, dengan dominasi lahan kering dengan iklim kering, dengan tipe iklim agak basah yang terdapat di 4 kabupaten, yaitu Ngada, Manggarai, Manggarai Timur dan Manggarai Barat. Sedangkan tipe iklim kering terdapat pada 5 kabupaten, yaitu Nagekeo, Ende, Sikka, Flores Timur, dan Lembata. Iklim di Flores dipengaruhi juga oleh angin munson dari Australia.

Perkembangan produksi sorgum di Kabupaten Ende dengan luas tanam 198 ha dan produktivitas 17 kuintal per ha, dan masih jauh dari produktivitas nasional, yaitu 2,73 ton per ha. Partisipasi petani terhadap penggunan pupuk pada usaha taninya tergolong rendah, termasuk usaha tani sorgum, petani cenderung melakukan budidaya tanpa olah tanah dan perawatan intensif. Tingkat adopsi teknologi cenderung rendah dan dukungan Pemerintah terhadap budidaya sorgum juga rendah. Pemerintah Daerah memfokuskan pada budidaya padi dan jagung sesuai dengan program Pemerintah Pusat. Pada akhirnya, terbentuk persepsi masyarakat yang rendah terhadap budidaya sorgum. Kondisi Agronomi ada di Kabupaten Ende memiliki potensi untuk mengembangkan sorgum yang dapat mendukung subtitusi pangan, untuk itu diperlukan pengkajian pengembangan sorgum secara agronomis.

Tujuan penelitian ini adalah untuk melakukan kajian agronomis pengembangan tanaman sorgum varietas Nambu dengan aplikasi pupuk kandang ayam.

\section{BAHAN DAN METODE}

Penelitian dilaksanakan di Kebun Percobaan Fakultas Pertanian, Universitas Flores, di Kelurahan Lokoboko, Kecamatan Ndona, Kabupaten Ende, dengan ketinggian tempat $500 \mathrm{~mm}$ di atas permukaa laut (dpl), curah hujan 1508$2750 \mathrm{~mm} / \mathrm{tahun}$, suhu $27^{\circ}-45^{\circ} \mathrm{C}$. Berdasarkan hasil analisis tanah, jenis tanahnya adalah lempung berpasir dengan $\mathrm{pH}$ mineral 5,7\%; C-organik 1,73\%; $\mathrm{N}$ total 0,15\%; P 17,25 ppm dan K 161,75 ppm (Tage, 2012). Penelitian dilakukan mulai bulan Desember 2019 sampai dengan bulan Mei 2020.

Bahan yang diperlukan dalam penelitian ini adalah bibit tanaman sorgum varietas Nambu dan pupuk kandang ayam. Sedangkan peralatan yang digunakan tugal, cangkul, parang, gembor, selang, tali raffia, timbangan, meteran, penggaruk, kalkulator, dan alat tulis.

Penelitan dilakukan dengan menggunakan rancangan acak kelompok (RAK), yang terdiri dari 5 perlakuan penggunaan pupuk kandang ayam, yakni: $A_{0}: 0$ ton per ha (kontrol), $A_{1}: 3,25$ ton per ha, $A_{2}: 6,5$ ton per ha, $A_{3}: 9,75$ ton per ha, dan $\mathrm{A}_{4}$ : 13 ton per ha. Percobaan dilakukan dengan 4 ulangan.

Pelaksanaan penelitian diawali dengan pengolahan tanah dengan membuat bedengan dengan ukuran $3 \mathrm{~m} \times 2 \mathrm{~m}$. Pupuk kandang ayam diaplikasikan satu minggu sebelum tanam dengan cara ditebarkan merata pada bedengan penelitian sesuai dosis perlakuan, yaitu $\mathrm{A}_{0}$ tanpa pupuk kandang, $\mathrm{A}_{1} 1,95 \mathrm{~kg}$ per petak, $\mathrm{A}_{2} 3,9 \mathrm{~kg}$ per petak, $\mathrm{A}_{3} 5,85 \mathrm{~kg}$ per petak, $\mathrm{A}_{4} 7,8 \mathrm{~kg}$ per petak. 
Penanaman dilakukan dengan membuat lubang dengan menggunakan tugal atau tongkat kayu yang dibuat runcing dan jarak tanam $50 \mathrm{~cm} \times 40 \mathrm{~cm}$. Setiap lubang tanam diisi dengan 2-3 benih, ditutup dengan tanah, dan setelah tumbuh dilakukan penjarangan dengan meninggalakan satu tanaman per lubang. Pemeliharan tanaman sorgum meliputi penyiraman, penyulaman, penyulaman dan penyiangan,

Tanaman sorgum dipanen pada umur 90 hari setelah tanam, dengan tanda-tanda setelah daun berwarna kuning dan mengering, biji bernas dan keras. Pemanenan dilakukan dengan memotong tangkai malai sepanjang 15-20 cm dari pangkal malai. Selanjutnya malai dijemur dan dirontok.

Dalam penelitian ini variabel-variable pertumbuhan yang diamati pada umur 28, 35, 42, 49, dan 56 hari setelah tanaman (HST) adalah: panjang tanaman $(\mathrm{cm})$, yang diukur dari pangkal batang sampai bagian ujung daun tanaman yang paling panjang dengan cara ditangkupkan; jumlah daun (helai), ditentukan dengan cara menghitung jumlah daun yang telah terbuka sempurna; luas daun $(\mathrm{cm})$, ditentukan dengan cara mengukur panjang $(\mathrm{P})$ dan lebar $(\mathrm{L})$ daun dengan meteran, selanjutnya luas daun diperoleh dengan menggunakan rumus $\mathrm{P} \times \mathrm{L} \times \mathrm{K}$, di mana konstanta $(\mathrm{K})=$ 0,72 (Agustina, 2010).

Varibel-variabel produksi yang diamati adalah: bobot brangkasan basah (g), dengan cara menimbang seluruh bagian tanaman; bobot brangkasan kering $(\mathrm{g})$, dengancaramenimbang bagian tanaman yang sudah dikeringkan dengan oven; panjang malai $(\mathrm{cm})$, diukur mulai dari pangkal malai (tempat tumbuhnya cabang malai) sampai ujung malai; jumlah bulir per malai (butir), dengan cara menghitung jumlah seluruh biji per malai; bobot malai kering ( $\mathrm{g}$ ), dengan cara menimbang seluruh berat kering malai; dan bobot 1000 biji (g), dengan cara menimbang 1000 biji kering yang diambil dari masing-masing perlakuan secara acak. Hasil pengamatan dianalisis dengan analisis ragam. Apabila perlakuan menunjukan pengaruh nyata terhadap variable yang diamati, maka dilanjutkan dengan uji BNT pada taraf 0,05 .

\section{HASIL DAN PEMBAHASAN}

Hasil analisis ragam dari variable-variabel pertumbuhan yang diamati menunjukan bahwa aplikasi pupuk kandang ayam memberikan pengaruh yang nyata terhadap tinggi tanaman, jumlah daun dan luas daun tanaman sorgum pada setiap umur pengamatan. Sebagaimana Tabel 1, pertumbuhan tinggi tanaman, jumlah daun, dan luas daun tanaman sorgum pada perlakuan tanpa pemupukan (kontrol) dibandingkan dengan perlakuan pupuk kandang ayam 3,25 ton per ha secara berturut-turut meningkat sebesar 7,18\%,7,27\% dan 11,37\%, penambahan dosis dari 3,25 ton per ha ke 6,5 ton per ha juga meningkat sebesar 4,55\%,5,03\% dan 1,77\%, untuk penambahan dosis dari 6,5 ton per ha ke 9,75 ton per ha juga meningkat sebesar 3,47\%,2,92\%, dan $11,74 \%$, demikian juga penambahan dosis dari 9,75 ton per ha ke 13 ton per ha meningkat sebesar $3,76 \%, 4,23 \%$ dan $10,72 \%$. Sehingga rata-rata persentase peningkatan tinggi tanaman adalah $4,74 \%$, jumlah daun $4,86 \%$, dan luas daun $8,9 \%$.

Tabel 1. Panjang tanaman, jumlah daun dan luas daun tanaman sorgum akibat aplikasi pupuk kandang ayam

\begin{tabular}{|c|c|c|c|c|c|c|}
\hline \multirow{2}{*}{ Variabel } & \multirow{2}{*}{ Perlakuan } & \multicolumn{5}{|c|}{ Umur Tanaman (HST) } \\
\hline & & 28 & 35 & 42 & 49 & 56 \\
\hline \multirow{6}{*}{$\begin{array}{l}\text { Tinggi Tanaman } \\
\text { (cm) }\end{array}$} & A0 & $88.58 \mathrm{a}$ & $111.42 \mathrm{a}$ & $154.78 \mathrm{a}$ & $207.72 \mathrm{a}$ & $262.58 \mathrm{a}$ \\
\hline & A1 & $98.22 \mathrm{~b}$ & $129.24 \mathrm{~b}$ & $166.48 \mathrm{~b}$ & $220.05 \mathrm{~b}$ & $270.36 \mathrm{~b}$ \\
\hline & $\mathrm{A} 2$ & $106.86 \mathrm{c}$ & $134.67 \mathrm{c}$ & $177.04 \mathrm{c}$ & $229.65 \mathrm{c}$ & $273.66 \mathrm{c}$ \\
\hline & A3 & $116.75 \mathrm{~d}$ & $140.28 \mathrm{~d}$ & $180.71 \mathrm{~d}$ & $237.22 \mathrm{c}$ & $275.52 \mathrm{~d}$ \\
\hline & A4 & $126.85 \mathrm{e}$ & $145.87 \mathrm{e}$ & $186.68 \mathrm{e}$ & $245.00 \mathrm{~d}$ & $277.08 \mathrm{~d}$ \\
\hline & BNT & 4.82 & 2.29 & 2.58 & 8.83 & 1.73 \\
\hline \multirow{6}{*}{$\begin{array}{l}\text { Jumlah Daun } \\
\quad \text { (helai) }\end{array}$} & $\mathrm{A} 0$ & $5.44 \mathrm{a}$ & $7.30 \mathrm{a}$ & $9.31 \mathrm{a}$ & $11.60 \mathrm{a}$ & $13.88 \mathrm{a}$ \\
\hline & A1 & $6.19 \mathrm{~b}$ & $8.06 \mathrm{~b}$ & $10.00 \mathrm{~b}$ & $12.19 \mathrm{~b}$ & $14.50 \mathrm{~b}$ \\
\hline & $\mathrm{A} 2$ & $6.69 \mathrm{c}$ & $8.38 \mathrm{c}$ & $10.44 \mathrm{c}$ & $12.56 \mathrm{c}$ & $15.00 \mathrm{c}$ \\
\hline & A3 & $7.13 \mathrm{~d}$ & $8.69 \mathrm{~d}$ & $10.50 \mathrm{c}$ & $13.00 \mathrm{~d}$ & $15.25 \mathrm{~d}$ \\
\hline & $\mathrm{A} 4$ & $7.44 \mathrm{e}$ & $8.94 \mathrm{e}$ & $10.94 \mathrm{~d}$ & $13.50 \mathrm{e}$ & $15.88 \mathrm{e}$ \\
\hline & BNT & 0.19 & 0.11 & 0.11 & 0.18 & 0.16 \\
\hline \multirow{6}{*}{ Luas Daun $(\mathrm{cm})$} & A0 & $1127.26 \mathrm{a}$ & $1798.94 \mathrm{a}$ & $3103.24 \mathrm{a}$ & $4700.24 \mathrm{a}$ & $6525.76 \mathrm{a}$ \\
\hline & A1 & $1387.12 \mathrm{~b}$ & $2078.55 \mathrm{~b}$ & 3491.42 b & $5165.62 \mathrm{~b}$ & $7083.81 \mathrm{~b}$ \\
\hline & $\mathrm{A} 2$ & $1584.82 \mathrm{c}$ & $2268.93 \mathrm{c}$ & $3753.82 \mathrm{c}$ & $5388.26 \mathrm{c}$ & $7488.20 \mathrm{c}$ \\
\hline & A3 & $1736.12 \mathrm{~d}$ & $2415.46 \mathrm{~d}$ & $3878.89 \mathrm{~d}$ & $5750.44 \mathrm{~d}$ & $7776.25 \mathrm{~d}$ \\
\hline & A4 & $1845.87 \mathrm{e}$ & $2442.97 \mathrm{e}$ & $4119.20 \mathrm{e}$ & $6197.70 \mathrm{e}$ & $8288.01 \mathrm{e}$ \\
\hline & & 72.15 & 54.42 & 77.03 & 129.80 & 103.64 \\
\hline
\end{tabular}

Keterangan: Angka-angka yang diikuti oleh huruf yang sama pada kolom yang sama menunjukan pengaruh yang tidak berbeda nyata pada taraf uji BNT 0,05 . 
Hal tersebut menunjukkan bahwa penggunaan pupuk kandang ayam dapat meningkatkan pertumbuhan tanaman, karena pupuk kandang ayam memiliki kandungan unsur hara N 1,5\%, P 1,3\%, K 0,8\% dan C-organik 9-11\%, dan cepat terurai dan cepat diserap bagi pertumbuhan dan perkembangan tanaman sorgum. Jika unsur hara yang terkandung dalam pupuk kandang ayam N 1,5\%, $\mathrm{P} 1,3 \%, \mathrm{~K} 0,8 \%$, aplikasi pupuk kandang ayam sebesar 13 ton per ha yang setara dengan N $195 \mathrm{~kg}, \mathrm{P} 169 \mathrm{~kg}$ dan K $104 \mathrm{~kg}$. Ini mengakibatkan pertumbuhan tanaman yang terbaik dan berbeda nyata dengan perlakuan lainnya. Hal tersebut menunjukkan bahwa pemberian unsur hara yang sesuai dengan kebutuhan hara untuk tanaman sorgum memberikan pertumbuhan yang bagus. Ini sesuai dengan hasil penelitian sebelumnya Suminar $e t$ al. (2018) bahwa tanaman sorgum dengan penambahan unsur hara $\mathrm{N} 161 \mathrm{~kg}$ dan $\mathrm{P}_{2} \mathrm{O}_{5} 43 \mathrm{~kg}$ menunjukkan performa pertumbuhan tanaman yang cukup baik.

Pupuk kandang ayam juga mengandung unsur hara mikro, sehingga memacu pertumbuhan tinggi tanaman, jumlah daun, dan luas daun yang opimal. Sementara itu, proses fisiologis di dalam tubuh tanaman tidak akan berjalan dengan baik apabila unsur hara tidak tersedia dalam jumlah yang memadai, terlebih unsur hara yang berperan dominan dalam pertumbuhan vegetatif tanaman, seperti unsur N. Menurut Subhan (2008), selain mengadung N dan P yang cukup tinggi, pupuk kandang ayam juga mengandung $\mathrm{K}$ yang tinggi, yang berperan sebagai aktivator enzim dalam metabolisme kabohidrat dan N, yang meliputi pertumbuhan, pemecahan dan translokasi pati, serta berpengaruh terhadap pengangkutan P. Pada proses fotosintesis $\mathrm{K}$ secara langsung mengacu pertumbuhan dan indeks luas daun, sehingga meningkatkan asimiliasi $\mathrm{CO}_{2}$ serta meningkatkan translokasi produk fotosintesis.

Jika dibandingkan dengan perlakuan tanpa pupuk kandang ayam (kontrol), perlakuan 3,25 ton per ha dapat meningkatkan rata-rata total bobot brangkasan basah, bobot brangkasan kering, panjang malai, jumlah biji per malai, bobot malai kering, dan bobot 1000 biji secara berturut-turut sebesar 12,93\%, 22,53\%, 5,42\%, 8,11\%, 44,5\% dan $15,04 \%$. Sedangkan peningkatan dosis perlakuan 3,25 ton per ha ke 6,5 ton per ha secara berturut-turut meningkat sebesar 10,34\%, 17,14\%, 5,8\%, 7,34\%, 15,34\% dan 9,16\%. Peningkatan juga terlihat pada perlakuan dosis 6,5 ton per ha ke 9,75 ton per ha juga meningkat sebesar $12,7 \%, 20,46 \%, 4,17,5,95 \%, 13,3 \%$, dan $6,78 \%$; demikian juga perlakuan dosis 9,75 ton per ha ke 13 ton per ha masih meningkat juga berturut-turut sebesar $11,19 \%, 17,29 \%, 5,4 \%, 5,38 \%, 8,4 \%$ dan 1,6\%. Dengan demikian, jika dilihat secara keseluruhan dari kontrol (tanpa pupuk kandang ayam) ke dosis 13 ton per ha, memberikan peningkatan nilai variabel-variable produksi sorgum rata-rata bobot brangkasan basah $11,79 \%$, bobot brangkasan kering 19,36\%, panjang malai 5,26\%, jumlah bulir per malai 6,69\%, bobot malai kering 20,39\%, bobot 1000 biji $8,14 \%$.

Hasil pengamatan terhadap variabel-variabel produksi disajikan pada Tabel 2. Variabel-variabel produksi juga menunjukkan peningkatan akibat aplikasi pupuk kandang ayam yang memiliki kandungan unsur-unsur hara makro $\mathrm{N}$ $1,5 \%, \mathrm{P} 1,3 \%, \mathrm{~K} 0,8 \%$, dan C-organik 9-11\% dan yang sifatnya cepat terurai, sehingga dapat diserap oleh tanaman sorgum. Selain itu, pupuk kandang ayam juga dapat memperbaiki sifat kimia, fisik, biologis tanah, sehingga perakaran tanaman dapat menyerap unsur-unsur hara dan air yang selanjutnya dapat meningkatkan pembentukan bunga, pembentukan biji, dan juga dapat menigkatkan laju fotosintesis. Fotosintat yang dihasilkan dari proses tersebut lebih baik ditranslokasikan pada pengisian biji, sehingga dapat peningkatan bobot brangkasan basah, bobot brangkasan kering, panjang malai, brangkasan malai kering, jumlah bulir, bobot 1000 biji.

Tabel 2. Bobot brangkasan basah, bobot brangkasan kering, panjang malai, jumlah bulir per malai, bobot malai kering, bobot 1000 biji sorgum akibat aplikasi pupuk kandang ayam

\begin{tabular}{ccccccc}
\hline \multirow{2}{*}{ Perlakuan } & \multicolumn{5}{c}{ Variabel Hasil } \\
\cline { 2 - 7 } & $\begin{array}{c}\text { Bobot } \\
\text { Brangkasan } \\
\text { Basah }(\mathrm{g})\end{array}$ & $\begin{array}{c}\text { Bobot } \\
\text { Brangkasan } \\
\text { Kering }(\mathrm{g})\end{array}$ & $\begin{array}{c}\text { Panjang Malai } \\
(\mathrm{cm})\end{array}$ & $\begin{array}{c}\text { Jumlah } \\
\text { Biji per Malai }\end{array}$ & $\begin{array}{c}\text { Malai Kering } \\
(\mathrm{g})\end{array}$ & $\begin{array}{c}\text { Bobot } 1000 \\
\text { Biji }(\mathrm{g})\end{array}$ \\
\hline A0 & $214.69 \mathrm{a}$ & $105.31 \mathrm{a}$ & $16.59 \mathrm{a}$ & $1055.00 \mathrm{a}$ & $9.19 \mathrm{a}$ & $5.31 \mathrm{a}$ \\
A1 & $246.56 \mathrm{~b}$ & $135.94 \mathrm{~b}$ & $17.54 \mathrm{~b}$ & $1148.06 \mathrm{~b}$ & $16.56 \mathrm{~b}$ & $6.25 \mathrm{~b}$ \\
A2 & $275.00 \mathrm{c}$ & $164.06 \mathrm{c}$ & $18.62 \mathrm{c}$ & $1238.94 \mathrm{c}$ & $19.56 \mathrm{c}$ & $6.88 \mathrm{c}$ \\
A3 & $315.00 \mathrm{~d}$ & $206.25 \mathrm{~d}$ & $19.43 \mathrm{~d}$ & $1317.31 \mathrm{~d}$ & $22.56 \mathrm{~d}$ & $7.38 \mathrm{~d}$ \\
A4 & $354.69 \mathrm{e}$ & $249.38 \mathrm{e}$ & $20.54 \mathrm{e}$ & $1392.19 \mathrm{e}$ & $24.63 \mathrm{e}$ & $7.50 \mathrm{~d}$ \\
\hline BNT & 6.45 & 3.51 & 0.09 & 5.99 & 0.82 & 0.30 \\
\hline
\end{tabular}

Keterangan: Angka-angka yang diikuti oleh huruf yang sama pada kolom yang sama menunjukan pengaruh yang tidak berbeda nyata pada taraf uji BNT 0,05

Aplikasi 13 ton per ha yang setara dengan $195 \mathrm{~kg} \mathrm{~N}, 169 \mathrm{~kg} \mathrm{P}, 104 \mathrm{~kg} \mathrm{~K}$ dapat memberikan peningkatan bobot brangkasan basah, bobot brangkasan kering, panjang malai, brangkasan malai kering, jumlah bulir, bobot 1000 biji yang optimal. Hal ini sesuai dengan hasil penelitian Suminar et al. (2018) bahwa tanaman sorgum dengan penambahan unsur hara $\mathrm{N} 161 \mathrm{~kg}$ dan $\mathrm{P}_{2} \mathrm{O}_{5} 43 \mathrm{~kg}$ menunjukkan tingkat produksi yang optimal

Penelitian penggunaan pupuk kandang ayam yang terbaik dan berbeda dibandingkan dengan perlakuan lainnya adalah perlakuan pemberian pupuk kandang ayam 13 ton per ha. Pelakuan ini memberikan nilai-nilai variable pertumbuhan tinggi tanaman $277,08 \mathrm{~cm}$, jumlah daun 15,69 helai, luas daun $8720,03 \mathrm{~cm}^{2}$, serta variable produksi yaitu 
bobot brangkasanan basah 354,69 g, bobot brangkasan kering 249,38 g, panjang malai 20,54 g, bobot malai kering 24,63 g, jumlah biji per malai $1392,19 \mathrm{~g}$, bobot 1000 biji 7,50 g.

\section{KESIMPULAN}

Kesimpulan-kesimpulan dari kajian ini adalah sebagai berikut:

1. Peningkatan dosis pupuk kandang ayam memberikan rata-rata peningkatan pertumbuhan dan hasil tanaman sorgum, pada tinggi tanaman 4,74\%, jumlah daun 4,86\%, luas daun 8,9\%, bobot brangkasanan basah $11,79 \%$, bobot brangkasanan kering 19,36\%, panjang malai 5,26\%, jumlah bulir per malai $6,69 \%$, bobot malai kering $20,39 \%$, bobot 1000 biji 8,14\%.

2. Aplikasi pupuk kandang ayam sebesar 13 ton per ha pada tanaman sorgum menghasilkan rata-rata tinggi tanaman $277,08 \mathrm{~cm}$, jumlah daun 15,69 helai, luas daun $8720,03 \mathrm{~cm}^{2}$, bobot brangkasanan basah $354,69 \mathrm{~g}$, bobot brangkasan kering 249,38 g, panjang malai 20,54 g, bobot malai kering 24,63 g, jumlah biji per malai 1392,19 g, bobot 1000 biji $7,50 \mathrm{~g}$.

Rekomendasi dari hasil kajian ini: tanaman sorgum berpotensi dan layak di kembangkan di Kabupaten Ende dengan aplikasi pupuk kandang ayam yang dianjurkan sebesar 13 ton per ha.

\section{UCAPAN TERIMAKASIH}

Ucapan terimakasih disampaikan kepada Pimpinan Universitas Flores, Pimpinan Fakultas Pertanian Universitas Flores, rekan-rekan dosen dan karyawan yang sudah banyak memberikan dukungan dan sarannya, serta semua tim peneliti yang telah bekerja sama dalam penelitian.

\section{DAFTAR PUSTAKA}

Andriani, A. dan M. Isnaini. 2013. Morfologi dan Fase Pertumbuhan Sorgum. Dalam: Sorgum: Inovasi Teknologi dan Pengembangan, p. 47-68. Maros Sulawesi Selatan.

BPS NTT. 2020. Provinsi Nusa Tenggara Timur Dalam Angka 2020. Badan Pusat Statistik Provinsi Nusa Tenggara Timur. ISSN/ ISBN: 0215-2223.

Gunawan, S., S.A. Sijid, dan Hafsan. 2017. Sorgum untuk Indonesia Swasembada Pangan (Sebuah Review). Prosiding Seminar Nasional, Biology for Life Gowa, 10 November 2017. Jurusan Biologi, Fakultas Sains dan Teknologi, UIN Alauddin Makassar. DOI: https://doi.org/10.24252/psb.v3i1.4807.

Human, S. 2011. Riset \& Pengembangan Sorgum dan Gandum untuk Ketahanan Pangan. Pusat Aplikasi Teknologi Isotop dan Radiasi, Badan Tenaga Nuklir Nasional, Jakarta.

Irawan, B. dan N. Sutrisna. 2011._Prospek pengembangan sorgum di Jawa Barat mendukung diversifikasi pangan. Forum Penelitian Agro Ekonomi 29(2): 99-113. DOI: http://dx.doi.org/10.21082/fae.v29n2.2011.99-113.

Kusumawati, A., N.E. Putri, dan I. Suliansyah. 2013. Karakterisasi dan evaluasi beberapa genotipe sorgum (Sorghum bicolor L) di Sukarami Kabupaten Solok. Jurnal Agroteknologi 4(1): 7-13. https://doi.org/10.24014/JA.V4I1.57.

Sirappa, M.P. 2003 . Prospek pengembangan sorgum di Indonesia sebagai komoditas alternatif untuk pangan, pakan, dan industri. Jurnal Litbang Pertanian 22(4): 133-140.

Subagio, H. dan M. Aqil. 2013. Pengembangan Produksi Sorgum Di Indonesia. Prosiding Seminar Nasional Inovasi Teknologi Pertanian, p. 199-214. Balai Pengkajian Teknologi Pertanian (BPTP) Balitbangtan Kalimantan Selatan, Banjarbaru.

Sumarno, D.S. Damardjati, M. Syam dan Hermanto. 2013. Sorgum (Inovasi Teknologi dan Pengembangan). Badan Litbang Pertanian. IAARD Press, Jakarta. ISBN: 978-602-1250-47-5.

Suminar, R., Suwarto, dan D.H. Purnamawati, D. H. 2018. Pertumbuhan dan hasil sorgum di tanah Latosol dengan aplikasi dosis pupuk nitrogen dan fosfor yang berbeda. Jurnal Agronomi Indonesia 45(3): 271-277. DOI: https://doi.org/10.24831/ jai.v45i3.14515.

Widowati, S. 2010. Karakteristik Mutu Gizi Dan Diversifikasi Pangan Berbasis Sorgum. Jurnal Pangan 19(4): 373-382. DOI: https://doi.org/10.33964/jp.v19i4.170. 